Dr ALEKSANDAR LUKIĆ, istraživač-saradnik

Institut za noviju istoriju Srbije

Beograd, Republika Srbija

alukic85@gmail.com

originalan naučni rad

UDK: 329.23(497.1)"192"

primljeno: 30. januar 2019.

323.1(=163.3/.6)(497.1)"192"

prihvaćeno: 9. oktobar 2019.

https://doi.org/10.29362/ist20veka.2020.1.luk.35-50

\title{
SRPSKI I HRVATSKI REPUBLIKANCI 1922. GODINE*
}

APSTRAKT: Srpski republikanci su od osnivanja Republikanske stranke januara 1920. u Beogradu bili suočeni sa malom podrškom stanovnika jugoslovenske monarhije. Nisu se obeshrabrili u svom političkom delovanju, nego su pokušali da sarađuju sa većinom političkih grupa koje su bile ili su mogle biti bliske njihovim političkim shvatanjima i stavovima. U tom smislu okrenuli su se Hrvatskoj republikanskoj seljačkoj stranci (HRSS) Stjepana Radića, koja je od izbora za Konstituantu novembra 1920. pokazala veliku snagu u političkom životu međuratne jugoslovenske monarhije. Međutim, već tokom 1921. godine doživeli su izvesna razočaranja u pogledu delovanja Stjepana Radića i HRSS prema jugoslovenskoj državi i ideji jugoslovenstva, ali nisu odmah odustali od pokušaja saradnje. Najveća aktivnost u približavanju stavova HRSS $i$ srpskih republikanaca odigrala se tokom 1922. godine, kada se pokazalo da saradnja nije ostvariva zbog drugačijeg cilja političkog delovanja Stjepana Radića i hrvatskih republikanaca. Odnos srpskih republikanaca $i$ hrvatskih nacional-republikanaca analiziran je $i$ prikazan u radu na osnovu izvora pohranjenih u Arhivu Srpske akademije nauka $i$ umetnosti, Arhivu Jugoslavije, Hrvatskom državnom arhivu u Zagrebu, štampe, periodike i relevantne istoriografske literature.

KLJUČNE REČI: Jugoslovenska republikanska stranka, Hrvatska republikanska seljačka stranka, Ljubomir Stojanović, Stjepan Radić, jugoslovenska monarhija, jugoslovenska ideja

Logično je, i moglo se očekivati, da će se posle uspostavljanja monarhijskog centralističkog državnog uređenja sve važnije republikanski orijentisane stranke grupisati u jedan zajednički front protiv nametnutog ustavnog rešenja. Još u vreme državnog provizorijuma države Srba, Hrvata i Slovenaca Ljubomir Stojanović i Jaša Prodanović, vođe Jugoslovenske republikanske stranke u Beogradu, uspostavili su veze sa vođstvom Hrvatske republikanske seljačke stranke, političke snage koja je u roku od nekoliko godina postala najjači činilac političkog živo-

\footnotetext{
* Rad je deo projekta Srbi i Srbija u jugoslovenskom i međunarodnom kontekstu: unutrašnji razvitak i položaj u evropskoj / svetskoj zajednici (47027), koji finansira Ministarstvo prosvete, nauke i tehnološkog razvoja Republike Srbije
} 
ta Hrvatske. Njen šef Stjepan Radić, poreklom iz Trebarjeva Desnog više Siska, već se početkom 1919. godine pripremao za političku ofanzivu distancirajući se naglašeno od čina proglašenja jugoslovenskog ujedinjenja i stvaranja Kraljevstva Srba, Hrvata i Slovenaca. Bogdan Krizman je uočio da je „Radić dobro osetio“ da dolazi njegovo vreme, odnosno vreme Hrvatske republikanske seljačke stranke, čiji je osnivač i šef bio sve do smrti 8 . avgusta 1928. godine. ${ }^{1}$

Pošto se vratio iz Praga Stjepan Radić je 20. decembra 1918. održao sednicu Glavnog odbora stranke, gde je otvoreno istakao svoj „republikanizam i mirotvorstvo“. Ubrzo je održana vanredna glavna skupština stranke u zagrebačkoj Streljani 3. februara 1919. godine, odakle su bile upućene teške reči na adresu režima u Beogradu povodom batinanja seljaka po Hrvatskoj i opšte privredne krize. Na skupštini je Stjepan Radić ponovio, jasno i glasno, zahtev za uspostavljanje „hrvatske republikanske države“ u okviru jedinstvene federativne Jugoslavije, države Slovenaca, Hrvata i Srba. Središnji odbor stranke je potom na sednici od 8. marta 1919. definisao Radićeve ideje kao želju hrvatskog naroda da „naša hrvatska država bude organizirana kao hrvatska neutralna seljačka republika“. ${ }^{2}$ Na reakciju državnih vlasti povodom istupanja Stjepana Radića i njegovih istomišljenika nije dugo trebalo čekati. Uhapšen je 25. marta 1919. i optužen da je radio protiv države tako što je Mirovnoj konferenciji u Parizu uputio protest protiv stvaranja Kraljevstva Srba, Hrvata i Slovenaca. ${ }^{3}$

Aktivnosti Stjepana Radića, u prvo vreme naizgled republikanskog karaktera, nisu ostale nepoznate ljudima u beogradskoj Republikanskoj stranci. ${ }^{4}$ Srpski republikanci su, iako u dugotrajnoj osnivačkoj fazi i suočeni sa mnogobrojnim problemima oko organizovanja stranke, pomno pratili dešavanja oko šefa hrvat-

\footnotetext{
${ }^{1}$ Bogdan Krizman, Korespondencija Stjepana Radića, knj. II (Zagreb: Sveučilište, Institut za hrvatsku povijest, 1973), 34.

${ }^{2}$ Isto, 60. O idejama Stjepana Radića u pogledu organizovanja Hrvatske u okvirima jugoslovenske monarhije: Mirjana Stefanovska, Ideja hrvatskog državnog prava i stvaranje Jugoslavije (Zemun - Beograd: Draganić, 1995), 265-329.

${ }^{3}$ B. Krizman, $n . d$., 36, 61 .

${ }^{4}$ Ljubomir Stojanović i Jaša Prodanović, dvojica prvaka Samostalne radikalne stranke u Kraljevini Srbiji i republikanskih vođa u Kraljevini Srba, Hrvata i Slovenaca/Jugoslaviji, uložili su veliki trud i rad u organizovanje Republikanske stranke u Beogradu i Srbiji tokom 1918-1919. godine. Iako ih većina političkih drugova iz bivše Samostalne radikalne stranke nije podržala u poduhvatu, uspeli su da krajem januara 1920. u Beogradu osnuju Jugoslovensku republikansku stranku. Jedna od četiri političke partije koja je u Kraljevini SHS/Jugoslaviji imala u svom nazivu odrednicu ,jugoslovenski“, JRS se zalagala za federativnu jugoslovensku republiku po ugledu na švajcarsko i francusko državno uređenje. Nije podržavala revolucionarne metode promene oblika države i socijalnih odnosa u društvu, ali je komunistima pružala podršku svaki put kada su ih monarhijske vlasti na nedemokratski i protivustavan način proganjale (primer Obznane). Ljubomir Stojanović je bio predsednik sve do smrti 1930, iako je već od proleća 1929. stranačkim poslovima stvarno rukovodio Jaša Prodanović. Arhiv Srpske akademije nauka i umetnosti (Arhiv SANU), Istorijska zbirka, Zaostavština Nikole Stanarevića, 14.329; Branislav Gligorijević, Parlament i političke stranke u Jugoslaviji: (1919-1929) (Beograd: Institut za savremenu istoriju, Narodna knjiga, 1979), 42-43; Isti, „Državno i društveno uređenje Jugoslavije u gledištima srpskih republikanaca (1919-1925)“, Istorija 20. veka, br. 2, (1985), 8-15; Mira Radojević, Naučnik i politika. Politička biografija Božidara V. Markovića (1874-1946) (Beograd: Filozofski fakultet, 2007), 321-331.
} 
skih republikanaca. Mada su drugovi Ljube Stojanovića - s obzirom na izjave i delovanje Stjepana Radića, koji su više upućivali na želju za ostvarenjem samostalne hrvatske države uz pomoć inostranog činioca nego za stvaranjem jedinstvene jugoslovenske države - vrlo rano hrvatski republikanski pokret označili, istina oprezno i uz mogućnost da greše, kao separatistički, nisu odmah u početku odbacili potencijalnu saradnju sa šefom hrvatskih republikanaca. Zato su često isticali da političke stranke nisu trebale da se organizuju na nacionalnom, već na političkom i socijalnom programu. ${ }^{5}$ Polazeći od zajedničke jugoslovenske osnove, nadali su se da im se vremenom mogu priključiti i sve ,pokrajinske stranke istog programa“, $u$ prvom redu partija Stjepana Radića kao najveća republikanska snaga u zemlji. ${ }^{6}$

Republikanska stranka je vrlo rano istakla da se po svom socijalnom programu i pogledima na uređenje jugoslovenske države u potpunosti razlikuje od „hrvatske struje“, koju je vodio Stjepan Radić. Izuzev jedine dodirne tačke - pitanja oblika državnog uređenja - srpski republikanci nisu se sa Stjepanom Radićem slagali „ni u čemu“. Smatrali su da jedinstvo jugoslovenske države nije dolazilo u pitanje ukoliko je oblik državnog uređenja bio upitan, naglašavajući da su ,separatističke ideje St. Radića“ (insistiranje na ostvarenju posebne hrvatske države uz podršku „talijanske“ vlade preko francuske misije u Zagrebu) u osnovi bile pogrešne i štetne. Međutim, većinu najbitnijih razloga koje je Stjepan Radić navodio da bi pokazao da monarhija u jugoslovenskoj državi nije bila legalno utemeljena - način obrazovanja Kraljevstva Srba, Hrvata i Slovenaca, činjenicu da za stvaranje Kraljevstva hrvatski građani ,nisu bili pitani“, da je republika bila bolja od monarhije, pošto je u njoj narod sam svoj gospodar, da je naposletku insistirao na nerešenom pitanju oblika državnog uređenja dok ga ne definiše nadležna buduća Konstituanta - isticali su i srpski republikanci, s bitnom razlikom što su te razloge, koji su bili „savršeno tačni“", proširivali na celu teritoriju jugoslovenske države, a ne samo prema Hrvatskoj. U tom smislu, „Radić je učinio veliki greh prema republikanskoj ideji“" vezujući je za ,separatistički pokret", čime je kod neobaveštenog javnog mnjenja unapred bacio senku na svaki drugi republikanski rad. Srpski republikanci ocenili su da je ,g. Radić republikanac i separatista“, dok su oni bili ,republikanci, ali za jedinstvo“. Odnosno, Stjepan Radić tražio je „Hrv. Seljačku Republiku“, dok su srpski republikanci zahtevali „Jugoslovensku Demokratsku Republiku“, uvereni da se narodno jedinstvo moglo najbolje i najsavršenije postići u demokratskoj republici, bez ikakvog nametanja rešenja oblika državnog uređenja s bilo koje strane. ${ }^{7}$

Ipak, u Radićevim zahtevima za uspostavljanje ,seljačke republike S. H. S“ srpski republikanci nisu videli ništa gore rešenje jugoslovenskog državnog pitanja u odnosu na predloge o uspostavljanju ,federativnog kraljevstva S.H.S“, koje su iznosili „,saveznici demokrata“ u vladi Milenka Vesnića. Radić nije mogao da

\footnotetext{
5 Jaša M. Prodanović, „Prenemaganje“, Republika, 4. 5. 1920, 1; „Stepan Radić“, Republika, 22. 6. 1920, 1-2.

${ }^{6}$ B. Gligorijević, „Državno i društveno uređenje Jugoslavije u gledištima srpskih republikanaca (1919-1925)“, 27.

7 „Stepan Radić“, Republika, 22. 6. 1920, 1-2.
} 
bude odgovoran zbog prava da propagira republikanske ideje u svom političkom delovanju. Ne samo u ono vreme, kada u jugoslovenskoj državi nije postojao jedan pravni režim, već se u njoj vladalo privremeno dok se očekivala suverena odluka Konstituante, i zbog čega su svi građani imali pravo da se javno zalažu za državno uređenje za koje su smatrali da je najbolje odgovaralo „,narodnim interesima“, nego uvek, ostajući u granicama slobode ustavom garantovane, svaki građanin i svaka politička partija imali su pravo da ,plediraju za republiku“. Stoga, propovedanje republikanskih ideja u monarhijama nije moglo da predstavlja politički zločin, niti nedozvoljenu radnju, zbog čega se Radiću nije smelo ,upisivati u greh“ njegovo republikanstvo. ${ }^{8}$ Principijelno braneći osnovna građanska prava u slučaju Stjepana Radića, odnosno pravo na slobodno političko opredeljenje i borbu za njegovo ostvarenje u granicama dozvoljenim zakonom, srpski republikanci su legitimisali svoj i hrvatski republikanski pokret i nagoveštavali, oprezno i sa dozom uzdržanosti, moguću saradnju sa šefom hrvatskih republikanaca.

Polazeći od uverenja da su tri jugoslovenska ,plemena“ mogla da se razvijaju kulturno i materijalno samo ujedinjeni u jugoslovenskoj državi, srpski republikanci su isticali u vreme izbornih borbi za Konstituantu da ni sam Radić, za koga su smatrali da je išao suviše daleko u zahtevima za pokrajinskom autonomijom, nije ,nikad“ bio protiv narodnog jedinstva, već protiv režima koji je vladao zemljom i načina na koji se njom upravljalo. Nezadovoljstvo hrvatskog seljaka jugoslovenskom državom moglo je stoga biti uklonjeno uspostavljanjem demokratske republike, u kojoj je trebalo da se svi delovi jugoslovenskog naroda osećaju slobodnim i ravnopravnim, i u kojoj je hrvatski seljak mogao da prestane sa tvrdnjama da se nalazio „pod Srbijom“.9 Republikanska stranka se približavala pojedinim tvrdnjama šefa hrvatskih republikanaca, s obzirom na to da njegove kritike na račun postupaka državnih vlasti u Hrvatskoj i Slavoniji prilikom ubiranja poreze i žigosanja stoke tokom 1920. godine nisu bile bez osnova. ${ }^{10}$

Uspeh hrvatskih republikanaca na izborima za Konstituantu podstakao je nadu kod srpskih republikanaca da se u jugoslovenskoj državi mogao uskoro stvoriti jedan široki republikanski front, koji je trebalo da dovede do uspostavljanja republike. Čestitke „monarhijskih političara“ Stjepanu Radiću povodom izbornog uspeha Republikanska stranka smatrala je ,ulizivanjem“ vođi hrvatskih republikanaca, s obzirom na to da je imao u Konstituanti zavidna 52 poslanička mesta. Da bi paradoks bio veći, jedino se stranka srpskih republikanaca držala po strani u „ovoj tragikomediji“‘. U novonastalim okolnostima videla je pred Stjepanom Radićem dve mogućnosti u daljem političkom delovanju. Ili je mogao da postupi kao ,jedan običan šarlatan, nemoralni političar" koji se republikanskom idejom poslužio samo da bi pridobio veliki deo hrvatskog naroda, s namerom da potom stupi u pregovore po principu ,ko da više vlasti, para, privilegija“. U tom slučaju Republikanska stranka ga je uvrštavala u neprijatelje re-

\footnotetext{
8 „Suđenje Stepanu Radiću“, Republika, 14. 7. 1920, 3.

9 „Monarhija i narodno jedinstvo“, Republika, 14. 10. 1920, 1-2.

${ }^{10}$ B. Krizman, n. d., 58, 60; B. Gligorijević, Parlament i političke stranke u Jugoslaviji: (19191929), 60, 79.
} 
publikanske ideje. Ili je, pak, kao ,čestit republikanski borac u najodlučnijim trenucima" imao da pokaže onoliko republikanske istrajnosti koliko je imao hrabrosti da izdrži ,„sve muke na koje ga je monarhija stavila“. ${ }^{11}$

U decembru 1920. boravilo je izaslanstvo HRSS u Beogradu zbog prethodnih poruka upućenih ovoj stranci od strane Stojana Protića, Jugoslovenskog i Muslimanskog kluba. Izaslanstvo je trebalo da se bolje upozna sa stavovima ovih činilaca o položaju Konstituante u političkom životu jugoslovenske države. Pri povratku s puta, izaslanici su u izveštaju Glavnom odboru istakli da ih je Republikanski klub srdačno primio, te da je Republikanska stranka bila idejno najbliža HRSS. Stavovi srpskih republikanaca o suverenosti, majorizaciji, izglasavanju Ustava dvotrećinskom većinom Srba, Hrvata i Slovenaca, te obliku državnog uređenja podudarali su se sa gledištima partije Stjepana Radića. ${ }^{12}$ Uskoro je jedna delegacija Glavnog odbora Republikanske stranke predvođena Milovanom Lazarevićem vodila pregovore u Zagrebu sa Stjepanom Radićem i predstavnicima HRSS 10. i 11. februara 1921. godine. ${ }^{13}$

Na sastanku su utvrdili polaznu osnovu za buduću saradnju, posebno ističući: da se prava narodna vladavina i demokratski režim nisu mogli ostvariti u jugoslovenskoj monarhiji već samo u republici, po prirodi svojih stanovnika seljačkoj sa idealima jugoslovenske i opšte čovečanske solidarnosti, građanske i ekonomske ravnopravnosti; da su se jedino potpuno slobodnim sporazumom mogli urediti zajednički odnosi i doneti ustav Srba, Hrvata i Slovenaca na osnovu potpune ravnopravnosti, zasnivajući politiku sporazuma na načelu ,seljačke federativne republike Jugoslavije“. Takođe, srbijanski republikanci priznali su načelo narodnog samoopredeljenja u svim pitanjima jugoslovenske unutrašnje politike, $s$ obzirom na to da se jugoslovensko jedinstvo nije moglo izvesti bez Hrvata; srpski republikanci su se uverili da Radićev pokret nije bio antidržavni, uperen protiv Srba, ,već protiv sistema koji u ime Srbije i Srba i pod maskom jedinstva, vrši nasilja po Hrvatskoj, razjedinjujući na taj način bratski narod Srba i Hrvata i sejući među njima mržnju i nepoverenje“. Konačno, HRSS je istakla da je saglasna sa programom i taktikom rada Republikanske stranke, te je kao znak priznanja trebalo da prihvati organ Republiku i smatra ga ,uglavnom svojim dnevnikom“, preporučujući ga svojim pristalicama kao takvog. ${ }^{14}$

11 „Stepan Radić“, Republika, 5. 12. 1920, 2.

12 B. Krizman, $n . d$., 70.

${ }^{13}$ Jovan Jovanović Pižon, šef Saveza zemljoradnika, pozvan je od Đure Basaričeka, sekretara Stjepana Radića, da dođe u Zagreb 10. februara 1921, kada je vodio informativne razgovore sa prvacima HRSS. Ostavio je zabelešku da su u Zagreb istovremeno došli „beogradski republikanci“ predvođeni Milovanom Lazarevićem, i da mu je Radić rekao kako se slagao sa njima u načelu, ali da su oni „doktrinari i nepraktični“. Odnosno, za Radića 1921. godine „Republika“ je bila ideal kojem se moglo težiti, ali ako nije moglo biti „Republike - onda ćemo videti - za sad narod Hrvatski to traži“. Po završenim razgovorima Jovan Jovanović Pižon stekao je utisak da je Radić hteo da dođe u Konstituantu, ali da je tražio način da spase formu: nije toliko bio vezan ,za Republiku ili za i jednu od odluka svojih koje je rastrubio po svetu“. Arhiv Jugoslavije (AJ), fond 80, Zbirka Jovan Jovanović Pižon, fascikla 31, arhivska jedinica 1.

${ }^{14}$ B. Gligorijević, ,Državno i društveno uređenje Jugoslavije u gledištima srpskih republikanaca (1919-1925)“, 28. 
Neučestvovanje poslanika HRSS u radu Konstituante srpski republikanci su kritikovali, budući da je njihovo odsustvo bitno olakšalo donošenje Vidovdanskog ustava. Republikanac Milovan Lazarević je istakao da su vladini poslanici imali najmanje razloga da se ljute na Radića, pošto niko monarhiji i vladi nije učinio veće koristi od šefa hrvatskih republikanaca. ${ }^{15} \mathrm{Na}$ kritike srpskih republikanaca zbog nedolaska u Konstituantu, Radić je odgovorio uopšteno da bi dolazak poslanika HRSS u Beograd značio ,odustajanje od njihovih zahteva“. ${ }^{16}$

Bez obzira na očigledne razlike u pogledu preuređenja jugoslovenske države (učešća/neučešća u parlamentarnoj proceduri i borbi u okviru jugoslovenske Skupštine) na federativnoj ili konfederativnoj osnovi (širok jugoslovenski ili usko-nacionalni hrvatski, odnosno srpski okvir), vođe srpskih republikanaca su nastojale da veze sa vođstvom HRSS iz vremena ustavne borbe održe i prodube posle donošenja Vidovdanskog ustava. Razgovori su vođeni preko opunomoćenih delegata dveju stranaka i u Beogradu i u Zagrebu. Stjepan Radić je ocenio da je prvi sastanak delegata HRSS i Republikanske stranke bio ,prvi ozbiljan i iskren pokušaj zbliženja Srba i Hrvata“, dok je Ljuba Stojanović ponovo naglasio u srpskom javnom mnjenju da se državno jedinstvo nije moglo postići bez Hrvata $\mathrm{i}$ Slovenaca, a osnova za to je bilo poštovanje njihove volje. ${ }^{17}$

Iskrena volja srpskih republikanaca za saradnjom i sporazumom sa HRSS prvenstveno se ogledala u priznanju postojanja hrvatskog pitanja, posle kojeg je po ozbiljnosti dolazilo makedonsko kao jedno od najvažnijih unutrašnjih pitanja jugoslovenske države. Sloga „Svih rodoljuba“ na rešavanju problematičnih pitanja i konsolidovanju države bila je veoma potrebna, ,ali sloga na pametan i dobar način; jer koliko je dobro i korisno u dobrom djelu pristati u slogu, toliko je i u rđavu ne pristajati“, citirali su republikanci Vuka Stefanovića Karadžića. ${ }^{18}$

Iz taktičkih razloga obe stranke nisu se odricale mogućnosti saradnje, ali su odnosi ubrzo ohladnili, pogotovo posle Radićevog stvaranja Hrvatskog bloka i otvorenog zalaganja za sporazum sa srbijanskim strankama na ,bazi konfederacije između republikanske Hrvatske i monarhističke Srbije“. ${ }^{19}$ Sve više se pokazivalo da šef hrvatskih republikanaca nije odustajao od ideje konfederacije i ostvarenja posebne nacionalne hrvatske jedinice vrlo upitnog državnopravnog položaja u okvirima jugoslovenske države. Naprotiv, u svojim zahtevima za preuređenje jugoslovenske države vremenom je bio sve neuračunljiviji i bezobzirniji u napadima na srpski narod, prvenstveno na Srbijance, označavajući ih neretko kao nosioce sveg zla u Kraljevini Srba, Hrvata i Slovenaca.

Kritikujući Srbe kao nosioce režima u državi, Stjepan Radić je otvoreno prozvao i srpske republikance, iako je istovremeno pokušavao da ostvari s njima saradnju. Navodno, kada je „,koji batinaš, ili kakav batinaški saveznik“ hteo „,to-

15 „Govor g. Milovana Lazarevića“, Republika, 1. 5. 1921, 2-3.

${ }^{16}$ B. Gligorijević, „Državno i društveno uređenje Jugoslavije u gledištima srpskih republikanaca (1919-1925)“, 29.

${ }^{17}$ Isto.

${ }^{18}$ Ljubomir Stojanović, „Konsolidovanje države (I)“, Republika, 26. 2. 1922, 1.

${ }^{19}$ B. Gligorijević, „Državno i društveno uređenje Jugoslavije u gledištima srpskih republikanaca (1919-1925)“, 29. 
bož mudro prigovoriti“ predstavnicima HRSS o njihovoj politici, pitao je da li zaista u Srbiji nije bilo moguće naći nekog za saradnju osim prokaženih radikala i demokrata; zar nisu postojali republikanci i zemljoradnici, zar nije tu bio srpski narod, ,a nada sve onaj ponosni i pravedni Šumadinac“. Istina, pisao je šef hrvatskih republikanaca, svi su navedeni činioci političkog života postojali u Srbiji, zbog čega ih je analizirao i prikazao „kakvi su to politički faktori“, a naročito, kako su se ponašali prema hrvatskom narodu i prema Hrvatskoj. ${ }^{20}$

I prvo je počeo od srpskih republikanaca. Za Radića republikanci u Srbiji su bili ,samo srbski, ili točnije - srbijanski republikanci“, pošto, prema mišljenju šefa HRSS, nisu imali pristalica izvan Srbije. Pa ipak, nazvali su se ,jugoslovenskom republikanskom strankom“, čime su načinili grešku nazivajući se onim što nisu bili. Prema saznanjima Radića, naziv nije predložilo vođstvo stranke, nego su ga ,izvikali študenti“, što je ,pogrešku“ samo povećavalo. Još više su srpski republikanci pogrešili što su 1921. godine išli u Zagreb da „hrvatsku republikansku većinu dovedu u Beograd“", odnosno što su insistirali na učestvovanju hrvatskih republikanaca u radu Konstituante kao bitnoj instituciji za borbu sa monarhijskim režimom. Najveća, pak, pogreška srpskih republikanaca ogledala se u činjenici da su od HRSS i od hrvatskog naroda tražili „mnogo više, nego li ista radikalskobatinaška vlada“. Radić se, očigledno, sablažnjavao što su srpski republikanci tražili da HRSS dođe u Beograd i „beogradsku skupštinu“, da „stupi sa zajedničkim programom s republikancima srbijanskim“, odnosno da se odrekne ,i seljačkog prava i konfederacije, svoga pacifizma“, te da se sa srpskim republikancima „primi posla, da i Šumadinca predobije za republiku“. ${ }^{21}$

Šef hrvatskih republikanaca nije sporio da je srpski narod bio ,zaista velik“, no nije video kraja njegovim mukama i patnjama, pošto su se ,sve gospodske stranke (a i republikanci su kao gospodska stranka)“", bile urotile protiv srpskog seljaštva. Šumadijski seljak bio je „razdvojen i rastrojen“, još uvek radikal, a to je za Radića bilo „kao da je hrvatski seljak frankovac“. Šumadijski seljak je bio i demokrat, ,a to je tako, kao da je hrvatski batinaš“; bio je i radikal i demokrat, ,,a to je tako kao da je hrvatski popovac (klerikalac - prim. A. L.)“. Narodu kojem nije sporio da je bio ,zaista velik“, na kraju je prikačio epitet da je bio ujedno ,i carista i komunista“, spreman da ,pokolje“ sve ,dahije i zelenaše“ o kojima je čitao u partijskoj štampi Saveza zemljoradnika ili Republikanske stranke. Navodno je bio i poneki pojedinac među šumadijskim seljacima koji je shvatio značenje seljačke republike, međutim nemoćan i uplašen usled osamljenosti. Ipak, Radić ih je označio kao ,jedinu budućnost Srbijinu“ i najjaču moralnu vezu Hrvatske sa Srbijom, pored koje je ,sve drugo u Srbiji vriedi[lo] za Hrvate išta ili ništa“. ${ }^{22}$

Pošto je šef hrvatskih republikanaca govorio i o Republikanskoj stranci na način koji nije odgovarao pravom stanju stvari, Ljuba Stojanović je smatrao za potrebno da odgovori na iznesene tvrdnje, te da celoj javnosti širom države Srba, Hrvata i Slovenaca tačno istakne šta su srpski republikanci zaista želeli i

\footnotetext{
${ }^{20}$ Stjepan Radić, „Ko je u Srbiji osim radikala i demokrata“, Slobodni dom, 13. 3. 1922, 2.

${ }^{21}$ Isto.

${ }^{22}$ Isto.
} 
radili. On je prvo pošao od naziva i karaktera Republikanske stranke. Osnivajući je srpski republikanci niti su mislili, niti želeli, niti je iz njihovog programa proizlazilo da su hteli da osnuju srpsku Republikansku stranku. S obzirom na to da je umesto predratne Srbije posle ,,pobednog rata“ nastala država Srba, Hrvata i Slovenaca, u novoj državi osnovali su Republikansku stranku, sa željom da u nju uđu i Slovenci i Hrvati i Srbi. Da bi se istakao jugoslovenski karakter prvi kongres Republikanske stranke uneo je odrednicu „Jugoslovenska“ u naziv partije, prelazeći tako preko uskih nacionalnih srpskih, hrvatskih i slovenačkih granica, i uzdižući do šireg državnog shvatanja sva tri naroda. Termin „Jugoslovenska“" nije, dakle, bio nikakva ,pogreška“ kako ju je video Stjepan Radić, već je označavao pravu nameru i cilj stranke na čijem čelu se nalazio Ljuba Stojanović. Sporo napredovanje ideje jugoslovenstva i republikanstva Lj. Stojanović je objašnjavao činjenicom da su obe bile za ,troplemeni narod još nove“, zbog čega je bio neophodan ,veliki broj apostola koji će ih propovedati“ ${ }^{23}$

Šef srpskih republikanaca je posebno insistirao na širenju ideje solidarnosti, s obzirom na to da je ostvarenje solidarizma u međunarodnom društvu značilo osiguranje mira, a u nacionalnom obezbeđenje socijalne pravde. $U$ tako ustanovljenom društvenom uređenju Ljuba Stojanović nije mislio da se od HRSS tražilo odricanje od ,seljačkog prava“, niti od pacifizma. Hrvatski republikanci mogli su uređivati seljačko pravo kao svoje unutrašnje pitanje kako su god hteli. U pogledu pacifizma, pitao se zar nisu i srpski republikanci bili pacifisti, imajući u vidu da su protivni bilo kojem osvajačkom ratovanju. Međutim, naglasio je, pacifizam nije bio unutrašnje već spoljno državno pitanje: „da se dva čoveka ne biju ne zavisi od jednoga, već od obojice. To isto“, rezonovao je republikanski trijumvir, ,važi i za dva naroda“. ${ }^{24}$

Za Ljubu Stojanovića pitanje (ne)dolaska hrvatskih republikanaca u Skupštinu bila je samo njihova stvar. Ipak, naglasio je da je Republikanska stranka smatrala korisnim dolazak HRSS u, ,čak i ovako rastočenu i uzetu (paralitičku) Skupštinu“, jer bi se onda na naredne izbore išlo „,s prečišćenim pojmovima i izašlo iz večite neodređenosti i lutanja“" u kojima se nalazio unutrašnji politički život jugoslovenske monarhije. ${ }^{25}$

U postskriptumu otvorenog pisma Ljuba Stojanović je izrazio želju da ono bude objavljeno i u Slobodnom domu, pošto se u prvom redu ticalo odnosa srpskih republikanaca sa HRSS. Stjepan Radić je ispoštovao njegovu želju i celo pismo odštampao, sa propratnim komentarom. Šef hrvatskih republikanaca izdvojio je dve stvari koje su u pismu Ljube Stojanovića „mnogo vriedele“. Prva se ogledala u činjenici da je Ljuba Stojanović, bez obzira što je pisao o „,celom narodu“, ipak Srbe, Hrvate i Slovence istakao kao tri naroda, te je jugoslovenstvo pravilno shvatao kao ,višu narodnu tvorbu“ koje ne samo da nije slabilo slovenstvo, hrvatstvo i srpstvo, nego ih je još više snažilo i učvršćivalo.

\footnotetext{
${ }^{23}$ Ljubomir Stojanović, „Gospodinu Stepanu Radiću, predsedniku H. R. S. S.“, Republika, 26. 3. 1922, 1.

${ }^{24}$ Isto.

${ }^{25}$ Isto.
} 
Druga vredna stvar bila je, prema mišljenju Stjepana Radića, izbor zajedničkih državnih poslova u duhu Ženevske konvencije i njenih zaključaka od 12. novembra 1918, prema kojoj su vojska i finansije bile zajedničke samo ukoliko su u pitanju zajednička odbrana i poslovi prema inostranstvu. ${ }^{26}$

Pored dve velike vrline, Stjepan Radić je primetio postojanje dva ,glavna grieha“. Prvi se ogledao u ,zaslepljenosti“ kojom se htelo da se „beogradska“ Republikanska stranka protegne na hrvatski narod, iako je bilo očigledno, smatrao je šef hrvatskih republikanaca, da su dva naroda mogla imati samo jedan politički pravac ili jednu orijentaciju, a nipošto jednu stranku (ono za šta je optuživao srpske republikance, Stjepan Radić je upravo činio svim snagama na užem nacionalnom nivou - HRSS je ,,protezao“ na ceo hrvatski narod), pa su zato samo ,hrvatski izrodi“ mogli da idu u ,batinaše, u radikale i zemljoradnike, eventualno i u ,jugoslavenske’ republikance“. Drugi veliki greh šefa srpskih republikanaca bila je „nepokolebljiva okorijelost“" s kojom je ,posve batinaški“ govorio o javnosti širom cele države. „Drugi veliki grieh“ Ljube Stojanovića u shvatanju Stjepana Radića u stvari je sadržavao više manjih ,podgrehova“: što je šef Republikanske stranke pisao da je mesto predratne Srbije postala posle ,,pobednog“ rata - ,a kako je postala o tom ni slovceta“ - država Srba, Hrvata i Slovenaca; što je tražio da do šireg državnog shvatanja dođu i, ,široke mase srpskog, hrvatskog i slovenačkog naroda“ i što je isticao da je republika ,jedini mogući oblik državnog jedinstva“ - kao da je ,glavna vriednost“, pisao je Stjepan Radić, „državnog shvaćanja“ bila u njegovoj teritorijalnoj širini, a ne u njegovoj socijalnoj dubini. ${ }^{27}$

Prozivke i optužbe Republikanske stranke od strane Stjepana Radića bile su, očigledno, bezobzirne i teške. Srpski republikanci su pokušali da istovremeno izglade sve otvoreniji sukob i razlaz, ali i da razjasne sporne tačke u dotadašnjim pregovorima sa HRSS. Uspeh u drugom rezultirao je neuspehom u prvom. Tako, istakli su da se republikanska Hrvatska mogla s pravom ponositi što je prva ,razvila i visoko uzdigla zastavu slobode, mira, ravnopravnosti i čovečnosti“", koju je držala uzdignutu ,čvrsto verujući“ u skoro ostvarenje njenih „,pravednih i opravdanih težnji“. Svojim postupcima jugoslovenska monarhija bila je već u ,grobu“, na kojem je trebalo da se razvije ,,jedna nova zajednica, Federativna Republika Južnih Slovena“, država „ljubavi i sloge među srodnim plemenima i narodima“ i simbol prve pobede prava ,radnika i čoveka““ ${ }^{28}$

Istovremeno, opominjući se vođenja pregovora sa predstavnicima HRSS u februaru i martu 1922. oko moguće buduće zajedničke saradnje, srpski republikanci su, posle oštrih napisa Stjepana Radića u pogledu Republikanske stranke krajem marta i početkom aprila, tražili da im odgovori na nekoliko pitanja u pogledu međusobnih odnosa dveju partija. Hteli su biti načisto sa Stjepanom Radićem, da bi se videla saglasnost ili nesaglasnost između usmenih raz-

\footnotetext{
${ }^{26}$ Stjepan Radić, „Srbijanski republikanci i HRSS“, Slobodni dom, 27. 3. 1922, 3.

${ }^{27}$ Isto.

${ }^{28}$ Boža L. Pavlović, „Republikanska Hrvatska“, Republika, 9. 4. 1922, 1. Slobodni dom, organ HRSS, preštampao je u celini tekst Bože Pavlovića, bez propratnih komentara (,Republikansko Jugoslovenstvo i republikanska Hrvatska“, Slobodni dom, 16. 4. 1922, 3).
} 
govora i pisanja šefa hrvatskih republikanaca odnosno Republikanske stranke, te da bi cela stvar bila „u opštem interesu, potpuno razjašnjena“. ${ }^{29}$ Pitanja je postavio Stanislav Milijanović, koji je u Zagrebu i pregovarao u ime Glavnog odbora Republikanske stranke.

Stanislav Milijanović je pitao Stjepana Radića da li je u ime HRSS, a po privatnoj inicijativi srpskog republikanca, uputio početkom februara 1922. predlog Republikanskoj stranci: da se predsedništva obe stranke sastanu u Slavonskom Brodu radi zvaničnih pregovora za sklapanje ,po mome (S. Milijanovića prim. A. L.) predlogu, republikanskog bloka, a po vašem, čak i koalicije“. Potom, da li je šef HRSS bio pristao da se pregovori vode „na bazi Jugoslovenske Federativne Republike“, i zbog čega se nije pojavio 19. februara u Slavonskom Brodu, iako su se prethodno obe strane dogovorile da se sastanu tog dana. Takođe, ako već nije mogao da dođe 19. februara, zašto se Stjepan Radić nije pojavio drugog dogovorenog datuma, 4. marta, nego je poslao svoje zamenike Josipa Predavca i Vlatka Mačeka. Milijanoviću nije bilo jasno zbog čega je Stjepan Radić insistirao da sastanku republikanaca prisustvuju i prvaci Zemljoradničke stranke Mihailo Avramović, odnosno Milan Komadinić. Dalje, zašto je šef HRSS, napadajući Republikansku stranku, istog dana napisao pismo prvaku napadnute partije Jaši Prodanoviću moleći ga (reč „molim“ je podvukao) da dođe u Zagreb i nastavi započete pregovore, da bi zatim 4. aprila Jašu Prodanovića označio kao centralistu. Srpski republikanac je tražio da mu Stjepan Radić potvrdi i pismeno da je rekao kako je zahvaljujući jedino „moralnoj potpori“ srpskih republikanaca uspeo da u kritičnim trenucima sačuva republikanski pokret u Hrvatskoj „da ne podlegne udarcima režima“. Uprkos tome, šef HRSS nije se ustručavao da pripadnike Republikanske stranke svrsta u „batinaše“, iako su zbog zalaganja za njega i republikanski pokret u Hrvatskoj bili izloženi progonu i batinama. Srpski republikanac je na kraju upitao zašto je Stjepan Radić pokušao da preko Svetislava Stefanovića, koji je u međuvremenu napustio Glavni odbor Republikanske stranke, izazove rascep u njoj, nazivajući Stefanovića „vođom neke nove srpske Republikanske Seljačke Stranke“. ${ }^{30}$ Stanislav Milijanović je ostavio Stjepanu Radiću vremena da odgovori do drugog narednog broja Slobodnog doma, posle čega je sebi ostavljao za pravo da piše o pokušaju srpskih republikanaca da solidarisanjem sa HRSS skinu ,anatemu“ sa nje da je bila protivdržavna, separatistička i izdajnička, te da se javno protivno utvrdi: da su i hrvatski republikanci bili za zajedničku državu, u kojoj su i Slovenci i Hrvati i Srbi trebali da budu ravnopravni članovi.

Stjepan Radić je prešao ćutke preko pitanja Stanislava Milijanovića, i neko vreme je rasprava između dveju republikanskih partija utihnula. Međutim, republikansko sporenje iz februara i marta nije prošlo nezapaženo među članovima i pristalicama obe republikanske stranke. Iako u Slobodnom domu za duži period nije bilo nikakve kritike niti osvrta na ishod pregovora sa Republikanskom strankom, ne znači da među hrvatskim republikancima nije bilo dvoumljenja i neslaganja u pogledu ispravnosti postupaka Stjepana Radića prema srp-

\footnotetext{
${ }^{29}$ Stanislav Milijanović, „Pismo g. Stjepanu Radiću“, Republika, 9. 4. 1922, 2.

${ }^{30}$ Isto.
} 
skim republikancima. Neki od mesnih prvaka HRSS su javno tražili objašnjenje o politici Stjepana Radića prema Ljubi Stojanoviću. Tako je Luka Kerepčić, predsednik HRSS iz Srednjeg Lipovca u Slavoniji, poslao Slobodnoj tribuni u Zagreb tekst pun negativne kritike na odnos Stjepana Radića prema srpskim republikancima i molio je da ga štampa, pošto je „Radiću doslovno pisao ovakovo pismo, i još preporučeno, i još marku metnuo za odgovor", ali je video „koliko on drži do seljaka, kad se nije udostojio ni riječi odgovoriti““.31

Da bi konačno razvejao moguće nejasnoće i raščistio odnose sa HRSS, Ljuba Stojanović je 26. jula 1922. uputio preko Republike otvoren proglas hrvatskim republikancima, u kojem je analizirao stanje u državi i dotadašnje odnose Republikanske stranke i HRSS. Kao i ranije, pozvao je sve republikanske snage u zemlji da se udruže protiv „razornog rada“ monarhističkih stranaka, koji je pretio da politički, ekonomski i moralno upropasti državu. U političkom pogledu zavođen je, prema mišljenju Ljube Stojanovića, „reakcionaran režim“, osnovan na nasilju, gaženju zakona i Ustava, sprečavanju osnovnih političkih sloboda i građanskih prava, na batinanju i prebijanju političkih protivnika (ne samo hrvatskih političara, nego i srpskih). Ekonomska propast ogledala se, pak, u pravljenju ,propaličkih zajmova“ i stvaranju ogromnog budžetskog deficita, u raskoši i luksuzu vrha državne uprave. Na kraju, opasnost je bila i moralna, budući da je korupcija rasla velikom brzinom i zahvatila najviše slojeve države, počev od vlade, Skupštine, vrhova vojske i crkve. „Sve žive sile narodne“, pisao je šef republikanaca, ,sva njegova moralna snaga u najvećoj su opasnosti““.32

Da se monarhija zameni republikom, bilo je potrebno da se svi republikanci u zemlji ujedine. Pokušaj da se do republike dođe pomoću nekog spoljnog činioca Ljuba Stojanović je smatrao opasnim po državnu nezavisnost i celinu. Trebalo je sopstvenim snagama da jugoslovenski republikanci legalnim putem zamene monarhiju federativnom jugoslovenskom republikom, po ugledu na Švajcarsku ili Sjedinjene Američke Države. Naglasio je da su srpski republikanci, bez „trunke plemenskog šovinizma“" i bez težnje za hegemonijom bilo koga, bili oduševljene pristalice federativne republike, u kojoj su želeli da zavlada potpuna verska i nacionalna ravnopravnost $\mathrm{i}$,najbolja“ socijalna pravda, odnosno postojala najveća moguća izjednačenost društvenih klasa i narod (,seljak“) bio potpuni gospodar u državi. ${ }^{33}$

Ljuba Stojanović je istakao da je Republikanska stranka učinila sve što je do nje stajalo da stupi u vezu i ostvari sporazum i saradnju sa HRSS. Naveo je istorijat odnosa dveju strana, i objavio neka dokumenta koja je smatrao bitnim za bolje razumevanje odnosa srpskih i hrvatskih republikanaca. Posebno je izdvojio pismo Stjepana Radića srpskim republikancima od 6. februara 1922, u kojem je šef hrvatskih republikanaca naglasio da je jugoslovenska federativna republika, za koju se zalagala Republikanska stranka, bila „baza“ za sporazum dveju republikanskih partija. Stjepan Radić se nije pojavio na zakazanim

\footnotetext{
31 „Jedna poruka Stepanu Radiću“, Republika, 21. 5. 1922, 1-2.

${ }^{32}$ Ljubomir Stojanović, „Hrvatskim republikancima“, Republika, 29. 6. 1922, 1.

${ }^{33}$ Isto.
} 
sastancima u martu, nego je u jednom napisu iznenada napao i srpske republikance, nazivajući ih ,batinašima“. Istovremeno je poslao pismo i tražio da se sastane sa Jašom Prodanovićem, što je Ljuba Stojanović takođe u celini objavio u proglasu, kao i svoj odgovor na optužbe Stjepana Radića u pogledu Republikanske stranke. Da bi oslabio uticaj odgovora Ljube Stojanovića, Stjepan Radić je isti propratio ,nepromišljenim i suprotnim istini tvrđenjima“ 34

Ljuba Stojanović se pitao zbog čega je Stjepan Radić tako postupao, zašto je zakazivao sastanke, pa ih odlagao i nije dolazio na njih. Stjepan Radić je izjavljivao da nije imao nikakvih rezervi prema republikanskoj Srbiji i pristajao na federativnu republiku, da bi zatim napao „nepravično“ i bezrazložno Republikansku stranku i pojedine njene članove, te iznosio tvrđenja koja nije mogao ničim dokazati, iako je davno bio prošao rok da podnese dokaze za optužbe iznete na račun srpskih republikanaca. Zbog čega je podrugljivo nazvao srpske republikance batinašima, kada su oni bili odlučni protivnici nasilja i bezakonja, branili progonjene, pa „,i njegovu stranku i komuniste“, izgubili ionako nevelik broj pristalica zbog pregovora sa HRSS, i čiji su redaktori bili mučki isprebijani od žandarma, a Republika bila zabranjena ,29 puta na 47 brojeva“ u toku prvih šest meseci 1922. godine. Ljuba Stojanović tumačio je ponašanje Stjepana Radića delovanjem monarhista u Hrvatskom bloku, i, što je bilo još gore, uticajem separatista protivnih ujedinjenju ,pod ma kakvom firmom ono bilo“. ${ }^{35}$

Reakciju iz Zagreba na pisanje republikanskih prvaka nije dugo trebalo čekati. Iako je bio najviše poimence prozvan, odgovor nije uputio Stjepan Radić nego Ante Adžija, jedan od prvaka HRSS. Ante Adžija je u kritici napisa srpskih republikanaca dao prednost tumačenjima šefa HRSS. Potom je istakao da je seljačka republikanska većina na trećoj sednici republikanske zastupničke većine banske Hrvatske održanoj 10. i 11. februara 1921. u Zagrebu, a u prisustvu šestorice izaslanika Republikanske stranke na čelu sa Milovanom Lazarevićem, naglasila u Poruci regentu Aleksandru da je Mirovno veće u Parizu konačno odlučilo da Slovenci, Hrvati i Srbi dobiju jednu zajedničku teritoriju u međunarodnom smislu, ali da nije ni pokušalo, niti je imalo prava, da na istom međunarodno priznatom području ,nezavisnoj hrvatskoj državi i hrvatskom narodu nametne monarhiju uobće, a srbsku monarhiju napose“" 36

Prema mišljenju Ante Adžije srpski republikanci nisu imali prava da sumnjaju u političko držanje Stjepana Radića stavljajući ga „na federativnu probu“, niti su smeli da tvrde u ime Republikanske stranke da je šef HRSS bio separatista. Najmanje su, pak, imali prava da pitaju pristalice HRSS da li su hteli da prime ,tobož novo Radićevo gledište“،, navodno pozajmljeno od frankovaca, ili su ostajali i dalje za državno jedinstvo, čime su se stvarno odricali svog šefa i njegove politike. Ante Adžija je stavove zasnivao na Poruci iz februara 1921. godine, gde je istaknuto da je hrvatski državni Sabor 29. oktobra 1918. proglasio za nezavisnu državu Hrvatsku, Slavoniju i Dalmaciju sa Rijekom i Međumurjem, te predao Narodnom

\footnotetext{
${ }^{34}$ Isto, $1-2$.

${ }^{35}$ Isto, 2.

${ }^{36}$ Ante Adžija, „Stjepan Radić i srbijanski republikanci“, Slobodni dom, 30. 7. 1922, 5.
} 
vijeću vrhovnu vlast, ali bez ikakvih ovlašćenja da istu dalje prenosi. Sabor je zaključio da je stupio $u$,zajedničku, a nipošto jedinstvenu državu Slovenaca, Hrvata i Srba", u kojoj je Konstituanta trebalo da slobodno odredi oblik državne vladavine, bez ikakve majorizacije Hrvata prilikom pretpostavljenog glasanja. Srpski republikanci znali su dobro kako je došlo do uspostavljanja monarhijskog oblika državne vladavine, ali nisu bili ,kadri“ navesti kada su i kako Stjepan Radić i HRSS promenili stavove iznete u Poruci, te pozajmili ideje frankovaca. Ante Adžija je zaključio da su srpski republikanci hteli ostvariti u Beogradu republikanski blok, zanemarujući onda i Stjepana Radića i HRSS. Hrvatski republikanci trebalo je da odu u Beograd i postanu ,kraljevski republikanci“, a pošto to nisu uradili, rezonovao je Ante Adžija, za srpske republikance postali su frankovci. ${ }^{37}$

U stvari, Ante Adžija je naglasio da se iza celokupnog rada Republikanske stranke krila želja da neko od hrvatskih republikanaca ,uskoči u tabor“ srpskih republikanaca, ne bi li tako ostvarili režim koji je mogao da ujedini ono što je postojeći već bio razjedinio. Međutim, hrvatski republikanci nisu hteli u tome da učestvuju. Srpski političari, republikanci ili monarhisti, videli su spas u državnom jedinstvu, ,a to znači u jedinstvu srbskom“. Opaska Ante Adžije u suštini je bila tačna. Ne iznenađuje da su srpski političari ,,videli“ spas u državnom jedinstvu, budući da je jugoslovenska država bila jedinstven okvir u datim okolnostima koji je u granicama jedne države ujedinjavao najveći deo srpskog naroda. Jedino, tako nešto nije odgovaralo Hrvatima. Zato i nije čudilo Ante Adžiju što su protivnike državnog jedinstva srpski političari označavali odmah kao separatiste i protivdržavne elemente. Po toj logici, svi srpski političari su smatrali da su jugoslovenski narodi ,jedan narod srbski“. Pašić i Pribićević su ujedinjavali u srpstvu ,budžom (batinom) i toljagom“, a srbijanski republikanci su hteli federacijom. Međutim, hrvatski republikanci predvođeni Stjepanom Radićem bili su konfederalisti, a govore i dela svoga šefa smatrali su ,izražaj(em) volje cjelokupnoga hrvatskoga naroda" ${ }^{38}$

Ante Adžija je očigledno pomešao, namerno ili iz neznanja, stvari: zamerao je srpskim republikancima insistiranje na državnom jedinstvu, preko kojeg su navodno hteli da ostvare i srpsko nacionalno jedinstvo. U programu i idejama Republikanske stranke i njenih prvaka jasno su odvajani državno od nacionalnog jedinstva, i nisu poricane hrvatska ili slovenačka nacija, kao ni srpska. Srpsko nacionalno ujedinjenje je uistinu i bilo maksimalno ostvareno osnivanjem jugoslovenske države 1918. godine, kao uostalom i hrvatsko. Zašto su Hrvati onako uporno insistirali na posebnoj nacionalnoj državi, kada je u ondašnjim međunarodnim okolnostima, kao i današnjim, nisu mogli ostvariti u maksimalnom obliku - ako se izuzme Nezavisna Država Hrvatska, koja stvarno nije ni postojala kao država, s obzirom da nije bila u stanju ostvariti pun suverenitet i kontrolu nad teritorijom koju je proglasila svojom - ostaje pitanje bez konačnog odgovora. Milan Grol, jedan od prvaka Demokratske stranke Jugoslavije, tokom Drugog svetskog rata ne jednom je naglašavao da je Jugoslavija, ma ka-

\footnotetext{
${ }^{37}$ Isto, 5.

${ }^{38}$ Isto.
} 
ko da je bila nesrećna po Srbe i Hrvate, objedinjavala u najvećem broju i jedne i druge na njihovim matičnim teritorijama, odnosno obe su nacije bile ujedinjene svaka ponaosob u potpunosti, čime su ispunjavale ideju potpunog nacionalnog ujedinjenja na matičnim teritorijama. ${ }^{39}$

Jaša Prodanović je odmah reagovao povodom članka Ante Adžije, ističući da na proglase Republikanske stranke nije odgovorio direktno prozvan Stjepan Radić nego je to prepustio zastupniku iz Grubišnog Polja. „Bolje za njega (Ante Adžiju - prim. A. L.) da se nije ni javljao“, pisao je Jaša Prodanović, s obzirom na to da hrvatski republikanac nije bio u stanju da vodi lojalnu diskusiju. U Srbiji su već bili „siti i presiti“ sofističkih izvijanja i „nevernih“ saopštenja radikala i demokrata, i nije bilo potrebno da se ,taj stari espap“ liferuje i iz Hrvatske. Međutim, kad je već Ante Adžija krenuo na „nepohvalni adžiluk“, srpski republikanac bio je prinuđen da mu da i ,propratnicu“. 40

Jaša Prodanović je ukazao da je Ante Adžija ponovio ,besposlice i nagvaždanja g. Radićeva“, koja šef HRSS nije imao običaj da potkrepi činjenicama. „Mali i sitni“" srpski republikanci morali su „operisati“ sa činjenicama i razlozima, dok su ,za hrvatskog apostola“ bila dovoljna i prosta tvrđenja, ,pa čak i sibiliski nejasni nagoveštaji“،. Tako, i u Sveto pismo smelo se posumnjati, samo ne „u Radićeva priklapanja“. Jaša Prodanović je, ipak, bio primoran da odbaci dve tvrdnje Ante Adžije. Drugi republikanski trijumvir je porekao da je Republikanska stranka htela da bude jedna partija sa HRSS, te da je zahtevala od Stjepana Radića da prizna narodno jedinstvo. Srpski republikanci su želeli sporazum, a ne ujedinjenje sa HRSS, i državno, a ne narodno jedinstvo. Na državno jedinstvo Stjepan Radić je ,u svoje vreme pristao“, i to je bio fakat. Međutim, više nije tako mislio, i izvesno je bilo da je na njega neko uticao, a Jaša Prodanović je zaključio da su u pitanju bili frankovci, s obzirom na to da su drugi elementi u Hrvatskom bloku (Narodni klub) ne samo pristali na zajedničku državu, nego su bili i ministri u Vladi koja je „uništila“" suverenitet Konstituante. ${ }^{41}$

Jaša Prodanović je posebno osudio tvrdnju Ante Adžije da su svi srpski političari, dakle i srpski republikanci, zastupali gledište o jednom, srpskom narodu u državi. Nisu u pitanju bili omaška, greška ili zabluda prvaka HRSS, nego svesna i namerna neistina. Kao protivdokaze srpski republikanac je naveo činjenicu da je Ljuba Stojanović ne jednom imao ozbiljne i oštre polemike sa vladinim listovima zbog tvrdnji da Srbi, Hrvati i Slovenci nisu bili jedan narod. Republika je stalno protestovala protiv mestimičnog ,srpskog šovinizma“, tražila ravnopravnost Srba, Hrvata i Slovenaca i insistirala da se država zove Jugoslavija. Srpski republikanci nisu tražili da državno jedinstvo bude srpsko - program Republikanske stranke i njen rad ,odlučno su pobijali podmetanje g. Adžije“. Smatrali su da bez federativne države, organizovane kao Švajcarska ili SAD, nije bilo spasa Srbima, Hrvatima i Slovencima. Stjepan Radić je tražio pomoć i od Italije, najljućeg jugoslovenskog neprijatelja u međuratnom periodu

\footnotetext{
${ }^{39}$ Milan Grol, Londonski dnevnik: 1941-1945 (Beograd: Filip Višnjić, 1990), 333.

40 Jaša M. Prodanović, „Nelojalna diskusija“, Republika, 13. 8. 1922, 1.

${ }^{41}$ Isto.
} 
- koliko je to bilo opasno i besmisleno, nije trebalo ni dokazivati. Prema mišljenju Jaše Prodanovića, Stjepan Radić i njegova okolina živeli su u hipnozi i „opijali“" se sopstvenim frazama bez smisla i logike. U svemu i svakome priviđali su neprijatelje koji su hteli da im nešto otmu i da ih posrbe. Tako su se, bez plana i „kompasa“, hrvatski republikanci gložili i sa političkim saradnicima u Hrvatskom bloku. Srpski republikanci nisu mogli da očekuju bilo šta od hrvatske „snage bez očiju“, s obzirom da su pristalice HRSS nasrtale i na one „koje su uzeli u ortakluk“. „Vreme gradi kule po Kotaru, vreme gradi, vreme razgrađuje“, i ono je imalo vrlo brzo da pokaže da je put koji je izabrao Stjepan Radić bezizlazan. „Kad se bude vraćao s njega“, gotovo proročki je pisao Jaša Prodanović, „verovatno je da će se više kotrljati nego slaziti. Daj Bože“, vajkao se srpski republikanac, „da se ne zaustavi u naručju kakvog državotvornog ličnog režima, jer je svojim zagrljajem sa bivšim ministrima batinaškog režima pokazao da može da radi i sa onakim monarhistima“. ${ }^{42}$

Stjepanu Radiću bilo je jasno da od sporazuma sa srpskim republikancima nema ništa, a, za istinu, nije mnogo na njega ni polagao. Okrenuo se šef HRSS mnogo većim potencijalnim partnerima - Demokratskoj i, kad nije uspeo sa njom, Radikalnoj stranci (s kojom je na kratko pokušao saradnju 1923. godine). Do 1925. godine Stjepan Radić je uspeo da iskompromituje svaki mogući način saradnje sa politički unekoliko ispravnijim demokratama, a kada su ga radikali početkom iste godine smestili u zatvor, nije trebalo dugo vremena pa da pred Nikolom Pašićem kapitulira. Obistinilo se predviđanje srpskih republikanaca - da je šef HRSS mogao „da radi i sa onakim monarhistima“. Jedino, saradnja sa monarhijskim grupama u Skupštini uskoro je stala glave Stjepana Radića - poginuo je baš od radikala Puniše Račića 20. juna 1928. godine. Ne samo da nije došlo do saradnje i sporazuma srpskih sa hrvatskim republikancima, nego su posle skupštinske tragedije odnosi srpskog i hrvatskog naroda, nosećih nacija jugoslovenske države, pošli strmom stranputicom, sa krvavim epilogom u Drugom svetskom ratu.

${ }^{42}$ Isto. 


\section{REFERENCE}

- Gligorijević, Branislav. Parlament i političke stranke u Jugoslaviji: (19191929). Beograd: Institut za savremenu istoriju, Narodna knjiga, 1979.

- Gligorijević, Branislav. „Državno i društveno uređenje Jugoslavije u gledištima srpskih republikanaca (1919-1925)“. Istorija 20. veka, br. 2, (1985), 7-34.

- Grol, Milan. Londonski dnevnik: 1941-1945. Beograd: Filip Višnjić, 1990.

- Krizman, Bogdan. Korespondencija Stjepana Radića, knj. II. Zagreb: Sveučilište, Institut za hrvatsku povijest, 1973.

- Petranović, Branko. Istorija Jugoslavije: 1918-1988, knj. I. Beograd: Nolit, 1988.

- Radojević, Mira. Naučnik i politika. Politička biografija Božidara V. Markovića (1874-1946). Beograd: Filozofski fakultet, 2007.

- Stefanovska, Mirjana. Ideja hrvatskog državnog prava i stvaranje Jugoslavije. Zemun - Beograd: Draganić, 1995.

ALEKSANDAR LUKIĆ, PhD, Research Associate

Institute for Recent History of Serbia

Belgrade, Republic of Serbia

alukic85@gmail.com

\section{SERBIAN AND CROATIAN REPUBLICANS 1922}

\section{Summary}

Serbian republicans gathered in the Yugoslav Republican Party (established in January of 1920. in Belgrade) were initially confronted with very limited support from the citizens of Serbia and from the Yugoslav monarchy in general. Nevertheless, they did not lose their will for carrying out political activities and they strived toward cooperation with most Yugoslav political groups that were or could have been close to Republican political points of view. Thus, they turned to the Croatian Republican Peasant Party, headed by Stjepan Radić, which showed great strength in the political life of the Kingdom of Yugoslavia after the election for the Constitutional Assembly in 1920. The most intensive period of attempts to reconcile the political stands of the Croatian Republican Peasant Party and the Serbian Republicans was in 1922. It turned out that cooperation was not possible because Stjepan Radić and the Croatian nationalrepublicans had different political goals.

KEYWORDS: Yugoslavian Republican Party, Croatian Republican Peasant Party, Ljubomir Stojanović, Stjepan Radić, Yugoslavian Monarchy, Yugoslav Idea 